\title{
Sarcomatoid Carcinoma of the Lung - a Case Report
}

\author{
Sarkomatoidní karcinom plic - kazuistika
}

\author{
Szkorupa M., Bohanes T., Neoral C., Vomackova K., Chudacek J. \\ Department of Surgery I, Faculty of Medicine and Dentistry of Palacky University Olomouc and University Hospital Olomouc
}

\begin{abstract}
Summary
Background: Sarcomatoid carcinoma (SARC) of the lung is a very rare and aggressive type of non-small cell lung cancer. It belongs to a group of poorly differentiated carcinomas with partial sarcomatoid differentiation or with a direct sarcoma component. Characteristic findings include a large tumor with an invasive tendency, early recurrence and systemic metastases. Case: The authors present a case of SARC in the 77-year-old patient. Preoperative staging confirmed sarcomatoid carcinoma of the lower lobe of the left lung without generalization on PET/CT. However, an infiltration of more than $2 / 3$ of the diaphragm was ascertained. A resection was performed - a left lower lobectomy with resection of the diaphragm and its replacement by a muscle flap made from the latissimus dorsi muscle with vascular pedicle. Histological findings confirmed the diagnosis of sarcomatoid (pleomorphic) carcinoma PT3NOMO. The patient underwent adjuvant chemotherapy; recurrence and systemic dissemination of the disease occurred after 20 months; the patient died 21 months after the surgery.
\end{abstract}

\section{Key words}

lung cancer - neoplasm invasion - surgical flaps - diaphragm - sarcomatoid carcinoma

\section{Souhrn}

Východiska: Sarkomatoidní karcinom (sarcomatoid carcinoma - SARC) plic patří mezi velmi vzácné a agresívní typy nemalobuněčného karcinomu plic. Jedná se o skupinu nízce diferencovaných karcinomů s částečnou sarkomatoidní diferenciací nebo prímo s komponentou sarkomu. Charakteristickým nálezem bývá objemný nádor se sklonem k invazi, brzká rekurence a systémové metastazování. Případ: Autoři prezentují případ SARC u 77leté pacientky. Předoperační staging prokázal sarkomatoidní karcinom dolního laloku levé plíce bez generalizace na PET CT, ale s infiltrací více než 2/3 bránice. Byla provedena resekce - dolní lobektomie s resekcí bránice a náhradou svalovým lalokem z m. latissimus dorsi na cévní stopce. Histologický nález potvrdil diagnózu sarkomatoidního (pleomorfního) karcinomu pT3NOMO. Pacientka prodělala adjuvantní chemoterapii, za 20 měsíců došlo k relapsu a systémové diseminaci nádoru, pacientka zemřela 21 měsíců od operace.

\section{Klíčová slova}

karcinom plic - nádorová invaze - svalový lalok - bránice - sarkomatoidní karcinom
The authors declare they have no potential conflicts of interest concerning drugs, products, or services used in the study.

Autoři deklarují, že $v$ souvislosti s předmětem studie nemají žádné komerční zájmy.

The Editorial Board declares that the manuscript met the ICMJE "uniform requirements" for biomedical papers.

Redakční rada potvrzuje, že rukopis práce splnil ICMJE kritéria pro publikace zasílané do biomedicínských časopisů.

\section{$\Xi^{\circ}$}

MUDr. Marek Szkorupa, Ph.D. Department of Surgery I Faculty of Medicine and Dentistry of Palacky University Olomouc and University Hospital Olomouc I. P. Pavlova 6

Olomouc

Czech Republic

e-mail: Marek.Szkorupa@fnol.cz

Submitted/Obdrženo: 15. 10. 2014

Accepted/Príijato: 2. 12. 2014

http://dx.doi.org/10.14735/amko201557 


\section{Introduction}

The diagnosis of sarcomatoid carcinoma (SARC) of the lung includes a group of poorly differentiated non-small cell lung tumors, which include a component with sarcomatoid differentiation (spindle-cell and/or giant cell population) or a sarcoma component. The incidence is only $0.1-1.3 \%$ of all malignant lung tumors [1]. They affect more frequently males than females (2-10:1), primarily smokers; the average age at diagnosis is 60 years [2]. SARC is characterized by rapid growth, invasion, disease recurrence and metastases.

\section{Case presentation}

The 77-year-old patient was examined due to shortness of breath, chest pain on the left side of the chest and dry cough. X-ray and CT findings showed a left-sided pleural effusion and a large heterogeneous tumor measuring $110 \times 95 \times 95 \mathrm{~mm}$. Endobronchial findings were with no direct signs of the tumor; cytology findings from brush biopsy were suspected to be malignant. A transparietal biopsy under CT was performed and diagnosed sarcomatoid granuloma. PET CT confirmed an extensive tumor arising from the lower lobe of the left lung with infiltration of approximately $2 / 3$ of the diaphragm, with no signs of invasion into the abdominal cavity or pericardium and with no signs of dissemination of the disease (Fig. 1). Laboratory findings showed only slight elevation of CA125, while other markers were with no pathological values. Primary staging was concluded to be CT3NOMO. The patient was indicated for surgical resection, which, due to the extent of the tumor, was performed through a double thoracotomy in the $5^{\text {th }}$ and $8^{\text {th }}$ intercostal space. The resection included a left-sided lower lobectomy and resection of $3 / 4$ of the surface of the diaphragm. The extensive defect resulting from the diaphragm resection was reconstructed using a muscle flap made from the latissimus dorsi muscle with vascular pedicle (Fig. 2). No serious complications were observed in the postoperative course (Fig. 3). The patient was discharged on the $14^{\text {th }}$ postoperative day.

Histological findings confirmed sarcomatoid cancer - pleomorphic subtype pT3NOMX, imunohistochemically positive vimentin $100 \%$, TTF1 5-20\%, AE1AE3 $80 \%$, only sporadic positivity of CK7. The patient subsequently underwent adjuvant chemotherapy with carboplatin and gemcitabine. PET CT performed 11 months after the resection showed the disease recurrence. Nine months later the patient complained of back pain, weight loss and weakness. Follow-up PET CT revealed disease recurrence with generalization. The patient died 21 months after the operation.

\section{Discussion}

The histogenesis of SARC remained unclear for a long time due to its histo-
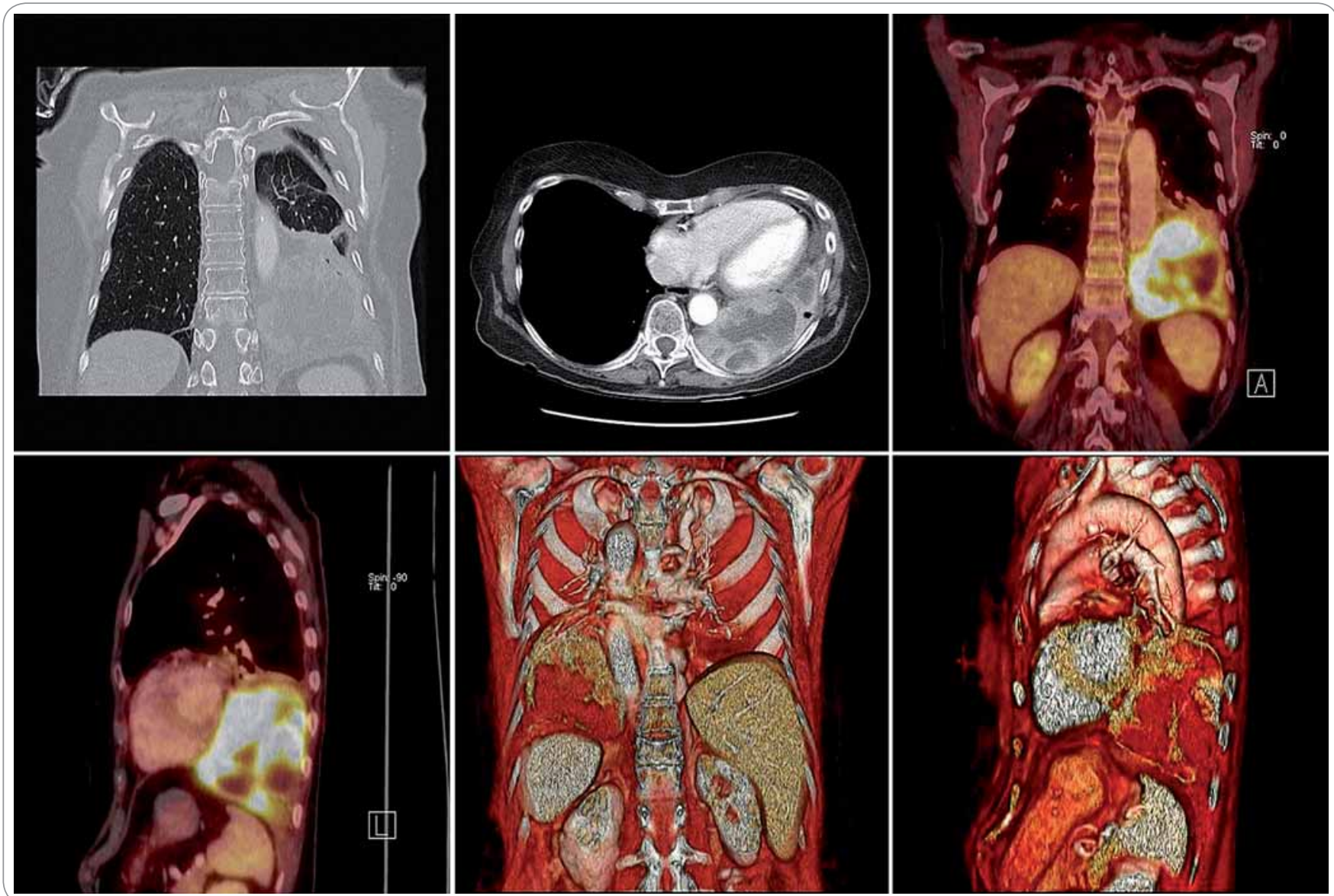

Fig. 1. CT images of the tumor before the surgery. The tumor arises from the lower left lung lobe and invades the diaphragm. 


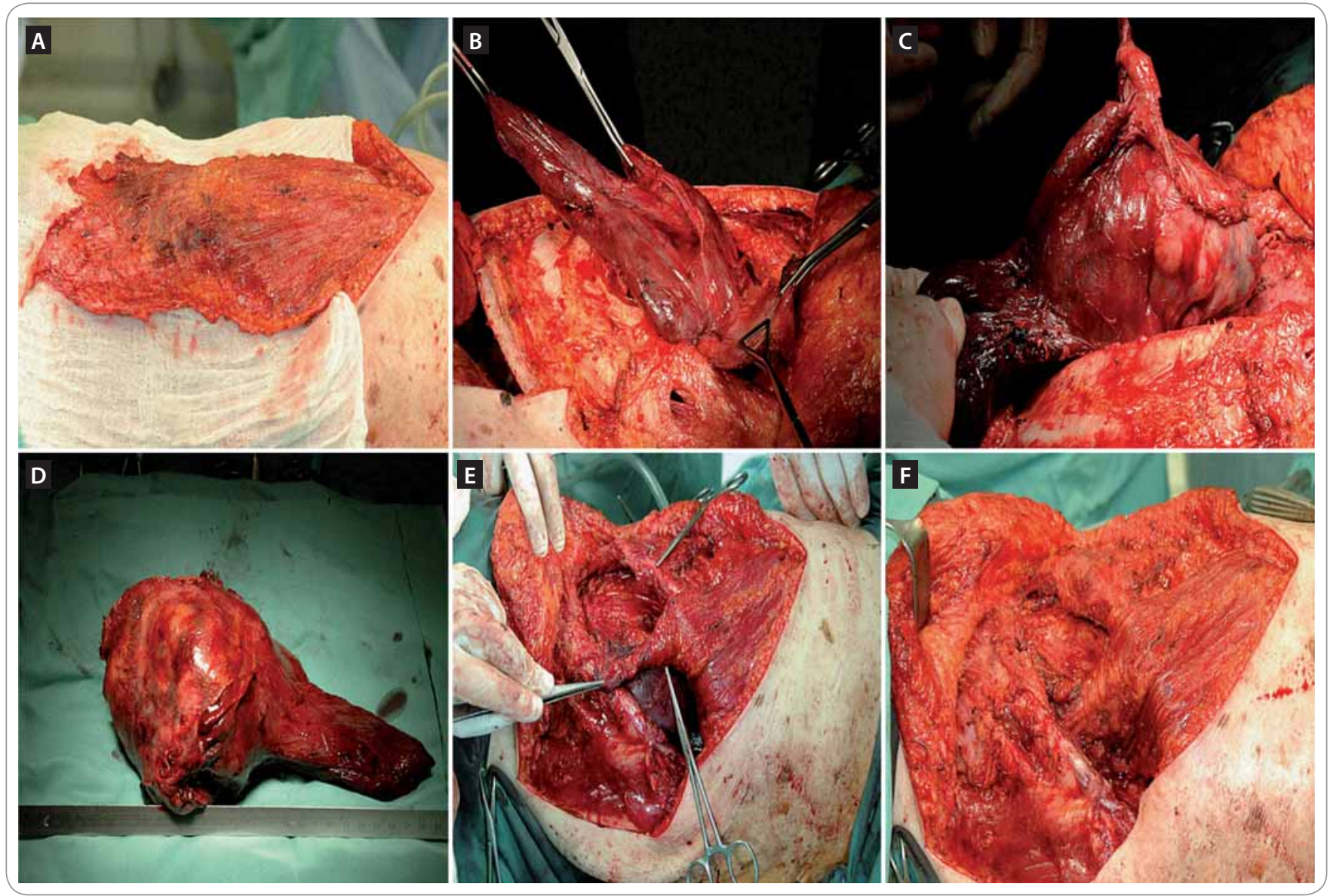

Fig. 2. Intraoperative pictures. A. preparation of the muscular flap; B, C. resection of the tumor with the diaphragm; D. the resected tumor; E, F. the diaphragm repair with the muscular flap.

logical heterogeneity. Years ago led this to the proposal of numerous theories. Only with the help of modern molecular methods could be the origin of sarcomatoid differentiation partially revealed. Currently, support for the so-called totipotent hypothesis prevails, which assumes the origin of the tumor cell to be from stem cells, which can differentiate into an individual epithelial or mesenchymal component [3]. This theory was also supported by the convincing determination of monoclonality and clonal identity of cell lines of carcinoma and sarcoma [4].

In an earlier WHO classification, individual types of SARC were included among conventional non-small cell cancers. Since 2004, the WHO classification has remained stable and the SARC group contains five subgroups - pleomorfic carcinoma, spindle cell carcinoma, giant cell carcinoma, carcinosarcoma and pulmonary blastoma [5].
Histopathological diagnosis of SARC and its subtypes may cause certain problems. Due to difficulties with capturing all the possible components, which may be within a tumor represented only in a minority, the tumor should be processed for histological analysis extensively. Certain subtypes may be identified by means of basic staining with hematoxylin-eosine; however, usually other methods must be used for specification. Immunohistochemical analysis must show cytokeratin positivity (most often AE1AE3, CAM5.2, CK18, CK7). Vimentin, CEA and smooth-muscle markers are also positive. Positivity of epithelial markers is not essential if components of conventional cancer are morphologically present [5].

To date, no prospective studies regarding SARC are available. This is primarily due to the low incidence of this type of carcinoma, and also due to more complicated diagnostics, when in a high number of cases it is recognized as late as according to the postoperative histological findings. Furthermore, due to tumor aggressiveness, majority of patients are SARC diagnosed in advanced stages or even upon autopsy. To date, only retrospective studies with mainly small numbers of patients with SARC have been documented, and these patients are usually compared to the groups of patients with conventional non-small cell cancer. These studies differ somewhat in their results. In most of these studies, patients with SARC had significantly worse results in terms of median of survival, disease progression as well as overall survival $[6,7]$. On the other hand, some studies did not find any difference in survival between the two aforementioned groups of patients $[8,9]$.

Nonetheless, SARC diagnosis is generally considered to be a disease with a significantly poorer prognosis in terms 


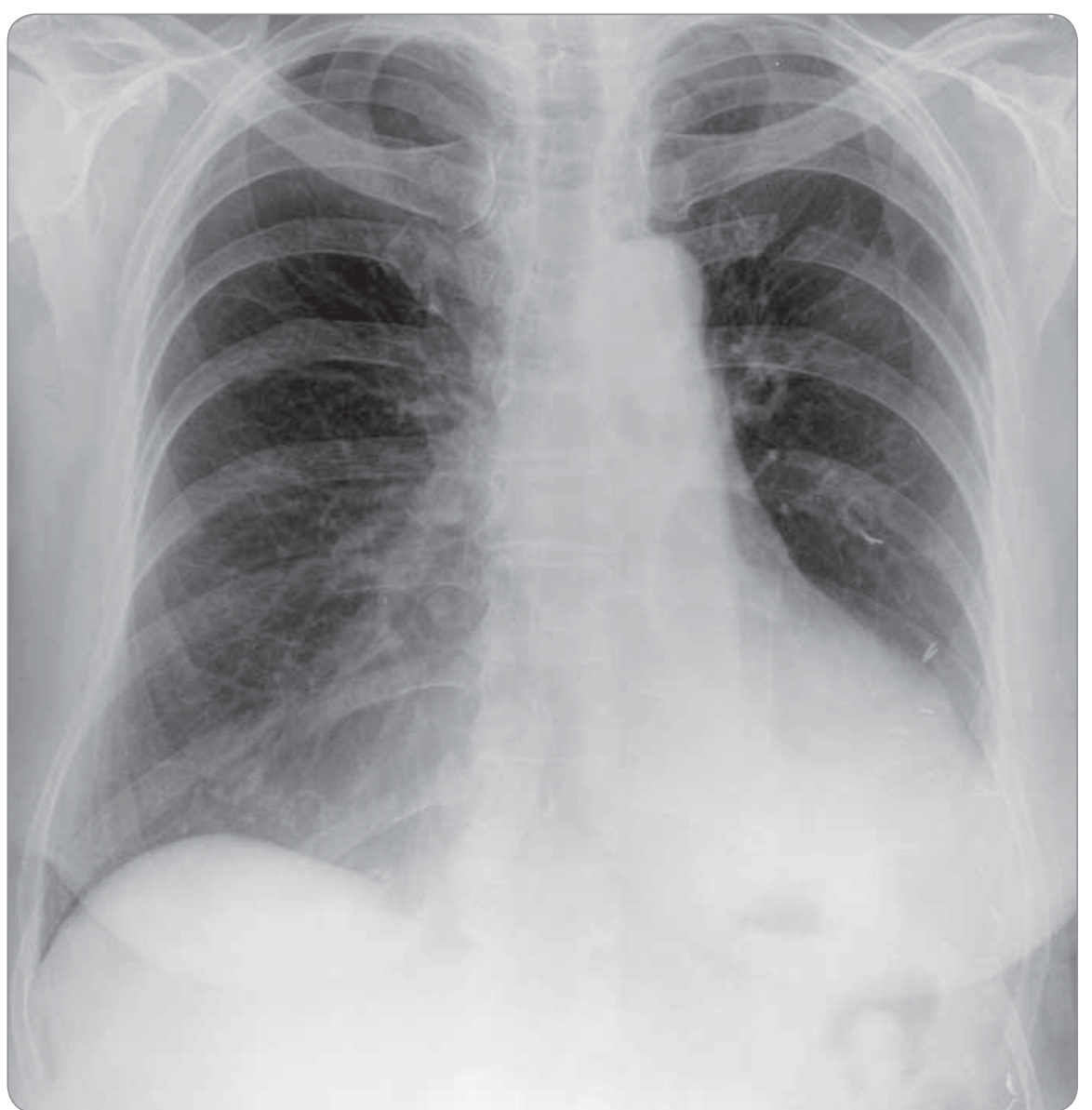

Fig. 3. Postoperative X-ray three months after the surgery.

of survival and early disease relapse. A complete resection in the early stages of disease brings the best results; however, five-year survival in stage I is achieved by only $37 \%$ of patients [10].
SARC has a low sensitivity to radiochemotherapy and improved responses to this modality have not been recorded, nonetheless it is recommended especially for bulky disease tumors, tumors invad- ing the thoracic wall or in cases of metastatic lymph node involvement. This is due to the higher incidence of locoregional and distant disease recurrence. In advanced stages, where surgical treatment is not indicated, palliative oncological therapy is recommended [7].

\section{References}

1. Travis WD (ed.). Pathology and genetics of tumours of the lung, pleura, thymus and heart. Oxford: Oxford University Press 2004

2. Kikuchi R, Isowa N, Tokuyasu H et al. Three cases of resected pleomorphic carcinoma. Ann Thorac Cardiovasc Surg 2010; 16(4): 264-269.

3. Wick MR, Swanson PE. Carcinosarcomas: current perspectives and an historical review of nosological concepts. Semin Diagn Pathol 1993; 10(2): 118-127.

4. Thompson L, Chang B, Barsky SH. Monoclonal origins of malignant mixed tumors (carcinosarcomas). Evidence for a divergent histogenesis. Am J Surg Pathol 1996; 20(3): 277-285.

5. Franks TJ, Galvin JR. Sarcomatoid carcinoma of the lung: histologic criteria and common lesions in the differential diagnosis. Arch Pathol Lab Med 2010; 134(1): 49-54.

6. Fishback NF, Travis WD, Moran CA et al. Pleomorphic (spindle/giant cell) carcinoma of the lung. A clinicopathologic correlation of 78 cases. Cancer 1994; 73(12): 2936-2945

7. Martin LW, Correa AM, Ordonez MG et al. Sarcomatoid carcinoma of the lung: a predictor of poor prognosis. Ann Thorac Surg 2007; 84(3): 973-980.

8. Nakajima M, Kasai T, Hashimoto $\mathrm{H}$ et al. Sarcomatoid carcinoma of the lung: a clinicopathologic study of 37 cases. Cancer 1999; 86(4): 608-616.

9. Pelosi G, Fraggetta F, Nappi O et al. Pleomorphic carcinomas of the lung show a selective distribution of gene products involved in cell differentiation, cell cycle control, tumor growth, and tumor cell motility: a clinicopathologic and immunohistochemical study of 31 cases. Am J Surg Pathol 2003; 27(9): 1203-1215.

10. Fujioka S, Nakamura $H$, Adachi $Y$ et al. Pleomorphic carcinoma of the lung in which the sarcomatous element grew rapidly: a case report. Ann Thorac Cardiovasc Surg 2009; 15(2): 111-114. 